\title{
Review
}

\section{Fas death receptor signalling: roles of Bid and XIAP}

\author{
T Kaufmann $^{*, 1}$, A Strasser ${ }^{2,3}$ and PJ Jost ${ }^{4}$
}

Fas (also called CD95 or APO-1), a member of a subgroup of the tumour necrosis factor receptor superfamily that contain an intracellular death domain, can initiate apoptosis signalling and has a critical role in the regulation of the immune system. Fas-induced apoptosis requires recruitment and activation of the initiator caspase, caspase-8 (in humans also caspase-10), within the death-inducing signalling complex. In so-called type 1 cells, proteolytic activation of effector caspases $(-3$ and -7$)$ by caspase-8 suffices for efficient apoptosis induction. In so-called type 2 cells, however, killing requires amplification of the caspase cascade. This can be achieved through caspase-8-mediated proteolytic activation of the pro-apoptotic Bcl-2 homology domain (BH)3-only protein BH3-interacting domain death agonist (Bid), which then causes mitochondrial outer membrane permeabilisation. This in turn leads to mitochondrial release of apoptogenic proteins, such as cytochrome $c$ and, pertinent for Fas death receptor (DR)-induced apoptosis, Smac/DIABLO (second mitochondria-derived activator of caspase/direct IAP binding protein with low Pi), an antagonist of X-linked inhibitor of apoptosis (XIAP), which imposes a brake on effector caspases. In this review, written in honour of Juerg Tschopp who contributed so much to research on cell death and immunology, we discuss the functions of Bid and XIAP in the control of Fas DR-induced apoptosis signalling, and we speculate on how this knowledge could be exploited to develop novel regimes for treatment of cancer.

Cell Death and Differentiation (2012) 19, 42-50; doi:10.1038/cdd.2011.121; published online 30 September 2011

\section{Facts}

- Activation of Fas by Fas ligand (FasL) can induce apoptosis by a mechanism involving the adaptor protein FADD (Fas-associating protein with a novel death domain) and the proximal initiator caspase, caspase-8 (and in humans also caspase-10).

- Apoptosis can only be triggered by the membrane-bound form of FasL.

- Caspase-8 can activate the Bcl-2 homology (BH)3-only protein $\mathrm{BH} 3$-interacting domain death agonist (Bid), enabling a crosstalk to the intrinsic apoptotic pathway. Whereas FasL-stimulated type I cells can die independently of the intrinsic apoptotic machinery, type II cells depend on this crosstalk to mitochondria.

- X-linked inhibitor of apoptosis (XIAP) directly inhibits effector caspases and constitutes a discriminator between the type I and the type II Fas-induced apoptosis signalling.

- Besides apoptosis, Fas can trigger several non-apoptotic signalling pathways, including RIP1 kinase-dependent cell death (necroptosis), when caspase-8 is missing or disabled, as well as pathways that promote cell activation and cell proliferation.

\section{Open Questions}

- How is Fas-induced necroptosis and proliferation regulated at the molecular level?

- What is the role of XIAP's RING domain in Fas signalling?

- Why are certain Fas-expressing cell types refractory to FasL-induced killing?

- What are the roles of soluble FasL?

\section{The Death Receptor Fas}

Fas (also called CD95 or APO-1) is a member of the tumour necrosis factor receptor (TNF-R) superfamily, which also includes receptors for TNF $\alpha$, TRAIL (TNF-related apoptosisinducing ligand), receptor activator of NF- $\kappa$ B ligand (RANKL), CD40 ligand (CD40L) and other members of the TNF family of cytokines. ${ }^{1}$ Specifically, Fas belongs to the subgroup of TNF$\mathrm{R}$ family members that have an intracellular death domain; this subgroup also includes TNF-R1, DR3 and the two TRAIL receptors, DR4 and DR5. ${ }^{1}$ The first and hereto bestcharacterised function of Fas is its ability to induce apoptosis in a large number of cell types. ${ }^{2}$ Besides apoptosis, a fundamental form of physiologically relevant programmed cell death in multicellular organisms, Fas and other so-called

\footnotetext{
${ }^{1}$ Institute of Pharmacology, University of Bern, CH-3010 Bern, Switzerland; ${ }^{2}$ The Walter and Eliza Hall Institute of Medical Research, Parkville, VIC 3052 , Australia; ${ }^{3}$ Department of Medical Biology, Melbourne University, Melbourne, VIC 3010, Australia and ${ }^{4}$ III. Medizinische Klinik, Klinikum rechts der Isar, Technische Universität München, D-81675 Munich, Germany

${ }^{*}$ Corresponding author: T Kaufmann, Institute of Pharmacology, University of Bern, Friedbühlstrasse 49, CH-3010 Bern, Switzerland. Tel: 41316323289 ;

Fax: 4131632 4992; E-mail: thomas.kaufmann@ pki.unibe.ch

Keywords: apoptosis; death receptors; Fas/CD95; Bid; XIAP; IAP antagonists

Abbreviations: $\mathrm{BH}(1-4), \mathrm{Bcl}-2$ homology domain (1-4); Bid, BH3-interacting domain death agonist; DR, death receptor; DISC, death-inducing signalling complex; FADD, Fas-associating protein with a novel death domain; FasL, Fas ligand; FLIP, FLICE-inhibitory protein; IAP, inhibitor of apoptosis; MOMP, mitochondrial outer membrane permeabilisation; TNF, tumour necrosis factor; TNF-R1, tumour necrosis factor receptor 1; TRAIL, TNF-related apoptosis-inducing ligand; Smac/DIABLO, second mitochondria-derived activator of caspase/direct IAP binding protein with low pl; XIAP, X-linked inhibitor of apoptosis.

Received 16.6.11; revised 01.7.11; accepted 29.7.11; Edited by G Melino; published online 30.9.11
} 
Box 1 Juerg Tschopp - a trailblazer in death-receptor signalling

During his great career, Juerg Tschopp has shown great interest in the function, mechanisms of activation, and regulation of cellular proteases that are central for cell death and pro-inflammatory signalling pathways. In addition to his earlier groundbreaking work on perforin/granzymes, and his more recent discoveries and extraordinary contributions in the field of the inflammasomes (see other reviews in this commemorative issue), Juerg Tschopp was also among the pioneers to understand the molecular mechanisms of death-receptor signalling. His work covered several members of the TNF receptor superfamily, and some of his major contributions are listed below:

- First report, using knockout mice (1994), to show that cytotoxic T cells use both perforin/granzymes and FasL to kill target cells.

- Multiple reports that helped to understand FasL-Fas interaction at the molecular level (e.g. Holler et al. ${ }^{106}$ ); early evidence that membrane-bound FasL is a much more potent apoptosis inducer than soluble FasL (Schneider et al. ${ }^{14}$ ).

- Discovery of viral and cellular FLIP proteins and identification of their role as inhibitors of DR-induced cell death (Irmler et al. ${ }^{28}$ and Thome et al. ${ }^{31}$ ); also, the first report that FLIP can promote activation of $\mathrm{NF}-\kappa \mathrm{B}$ and $\mathrm{ERK}$-signalling pathways. Identification of role of FLIP $(\mathrm{L})$ in T-cell proliferation.

- One of the first reports that Fas can trigger RIP kinase-dependent non-apoptotic cell death, called necroptosis (Holler et al. ${ }^{3}$ ).

- Biochemical characterisation of the signalling complexes activated by TNF-R1 ligation; definition of complex I and complex II.

- Identification and characterisation of TRAIL-R2 and TRAIL-R3 (DR5 and DcR1, respectively). One of the first reports that TRAIL-R1 and -R2 signal apoptosis through a FADDand caspase-8-dependent pathway and can also activate $\mathrm{NF}-\kappa \mathrm{B}$.

- Identification of BAFF and APRIL, and their roles in the differentiation, proliferation and survival of B-lymphoid cells and in tumour growth.

death receptors (DRs), have recently also been implicated in the activation of the kinase RIPK1, resulting in a cell death with necrotic characteristics, termed necroptosis. ${ }^{3-6}$ Even though Fas, a trimeric plasma membrane-bound surface receptor, is expressed on most cell types throughout the body, it is of particular importance in the control of the immune system, where it functions as a guardian against autoimmunity and tumourigenesis. ${ }^{2}$ Although Fas and other DRs are clearly able to kill cells, it has become evident over the last decade that in addition, Fas can also activate several other, non-deathrelated signalling pathways, leading to differentiation or proliferation, ${ }^{7}$ a concept to which Juerg Tschopp has made seminal contributions (see Box 1).

In contrast to the broad tissue distribution of Fas, the expression of the physiological ligand for Fas, FasL (CD95L), is restricted to a highly selective cellular pool, including activated-T cells, NKT cells and NK cells. ${ }^{1,8}$ Expression of FasL on certain non-lymphoid tissues, such as the eye and testis, has also been reported, but this is controversial. ${ }^{1,9}$ Cells express FasL either in a membrane-bound form on their surface or, through the action of certain metalloproteases, such as ADAM10, ${ }^{10}$ FasL can be cleaved and released in a soluble trimeric form. After extended controversies, studies with fas/mutant mice generated by gene-targeting in ES cells, which can express either only membrane-bound FasL or only secreted FasL, have demonstrated beyond doubt that only the membrane-bound form of FasL is capable of inducing apoptosis, ${ }^{11}$ a result that had been predicted by Juerg

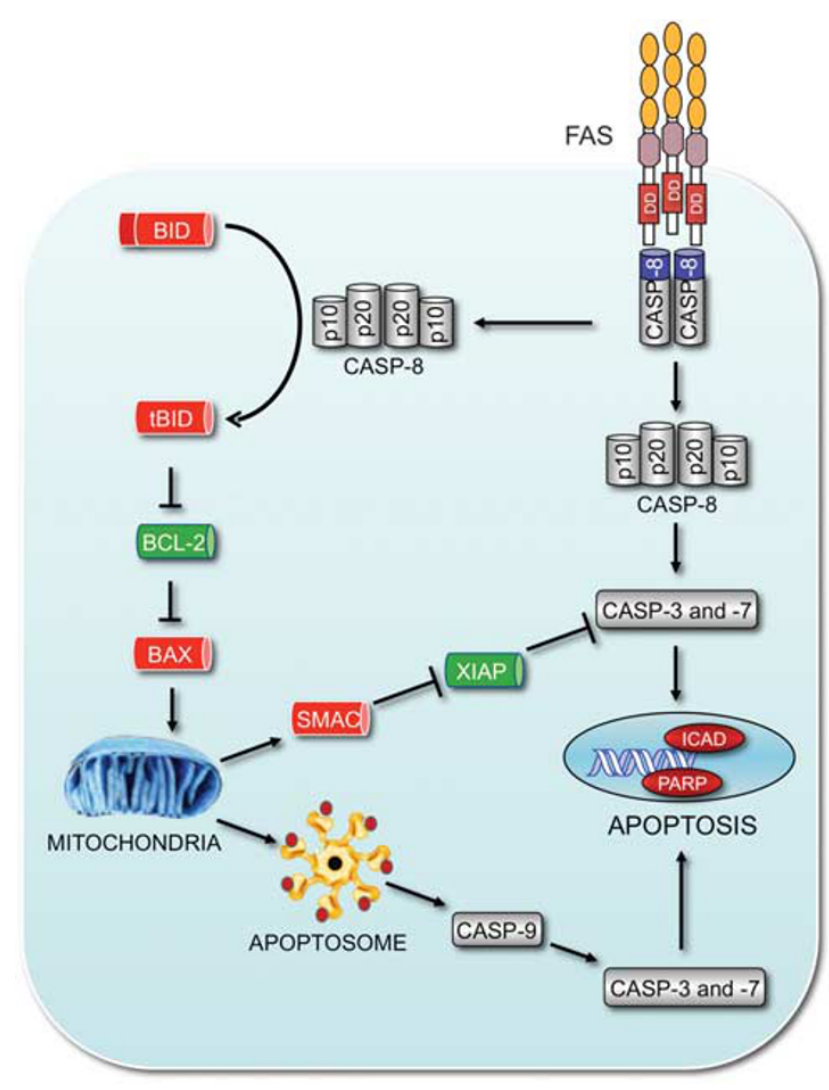

Figure 1 Fas-induced apoptotic signalling pathway. Whereas in the so-called type 1 cells (e.g. thymocytes, resting $T$ lymphocytes), activation of Fas rapidly proceeds from caspase- 8 activation to effector caspases ( -3 and -7$)$ activation and cell demolition, this direct pathway is relatively ineffective in type 2 cells (e.g. hepatocytes, pancreatic $\beta$-cells). In the latter, Fas-induced apoptosis requires caspase-8-mediated proteolytic processing of Bid into tBid, which transmits the apoptotic signal to the Bcl-2-regulated apoptotic pathway, activating Bax/Bak, thereby triggering MOMP with release of apoptogenic proteins. These include cytochrome $c$, required for apoptosome formation and caspase- 9 activation, as well as Smac/DIABLO, an antagonist of XIAP. XIAP is a potent inhibitor of active effector caspases, and thus constitutes an important attenuator of Fas-induced apoptosis signalling in type 2 cells

Tschopp on the basis of his laboratory's studies with recombinant forms of FasL. Biochemical studies have shown that for Fas to elicit apoptosis, there needs to be aggregation of multiple pre-assembled Fas trimers on the surface of responding cells. ${ }^{12}$ This can of course be achieved much more readily by membrane-bound FasL than by soluble FasL trimers. Although soluble trimeric FasL fails to trigger cell death, there is considerable evidence that it is involved in Fasinduced activation of NF- $\kappa \mathrm{B}$ and MAP kinases, and consequent initiation of signalling pathways that promote cell survival or processes unrelated to apoptosis, such as cell differentiation or inflammation. These functions of soluble FasL were first demonstrated by Juerg Tschopp and his colleagues, ${ }^{13}$ in experiments using recombinant ligand to stimulate tumour-derived cell lines or primary cells. Remarkably, knock-in mutant mice that lack membrane-bound FasL, but express secreted FasL, which is able to bind to its receptor Fas, succumb to diseases, including SLE-like glomerulone- 
phritis, autoimmune dermatitis and histiocytic sarcoma, considerably more rapidly than gld mutant mice that have a point mutation in FasL that prevents binding to Fas, and therefore, abolishes the function of both membrane-bound, as well as soluble FasL. ${ }^{11}$ This indicates that when membranebound FasL/Fas-induced apoptosis is blocked, soluble FasL/ Fas-induced activation of non-apoptotic pathways can enhance development of autoimmune disease and cancer, possibly by eliciting inflammatory responses.

The molecular events that are activated by FasL to trigger Fas-mediated apoptosis are well characterised (Figure 1). ${ }^{2}$ Membrane FasL leads to aggregation of pre-assembled Fas trimers on the plasma membrane of target cells. ${ }^{12,14-17}$ Aggregation-induced conformational changes in Fas lead to the formation of the death-inducing signalling complex (DISC), ${ }^{18}$ which involves recruitment of the adaptor protein FADD/Mort1 through a homotypic interaction of death domains, present in both the intracellular region of FAS and the C-terminus of FADD. ${ }^{19,20}$ Through a second homotypic interaction, involving death-effector domains present in the $\mathrm{N}$-termini of both FADD and pro-caspase-8, the initiator caspase (as well as procaspase-10 in humans) is recruited into the DISC. ${ }^{19,21}$ Caspase- 8 is an aspartate-specific cysteine protease, which is present in healthy cells as an inactive proenzyme (zymogen). Through complex proximitydriven conformational changes, full-length procaspase-8 molecules within the DISC gain full enzymatic activity, resulting in the auto-proteolytic processing of caspase-8 into large ( p20) and small ( p10) subunits, and assembly of a

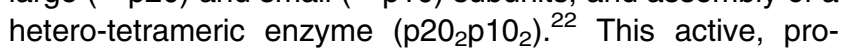
cessed caspase-8 can leave the DISC to target its specific substrates within the cytosol, such as effector caspases (caspase-3, caspase-7) and the pro-apoptotic BH3-only protein Bid, which are all critical for Fas-mediated apoptosis. ${ }^{23-27}$ Work by Juerg Tschopp and others has shown that caspase- 8 activation within the DISC can be regulated positively or negatively by cellular FLICE-inhibitory protein (c-FLIP), a protein structurally resembling caspase-8, but lacking a catalytic site. ${ }^{28}$ Low concentrations of $C-F_{L} P_{L}$ promote caspase- 8 recruitment and activation, whereas high concentrations of $\mathrm{C}-\mathrm{FLIP}_{\mathrm{L}}$ inhibit capase-8 activation, likely due to competition for FADD interaction. ${ }^{22}$ Isoforms of C-FLIP lacking its caspase-like domain (c-FLIPs and C-FLIP $P_{R}$, the only short c-FLIP isoform expressed in the mouse, ${ }^{29}$ ), as well as viral forms of FLIP act solely as potent inhibitors of caspase- 8 recruitment and activation. ${ }^{29-31}$

\section{The Bcl-2 Protein Family and its Role in the Regulation of Apoptosis}

Members of the Bcl-2 protein family have a major function in regulating apoptosis in a broad range of species, ranging from nematodes to man. ${ }^{32}$ This protein family regulates an apoptotic pathway that is largely distinct from the DR-induced apoptosis signalling pathway, ${ }^{33}$ although the two pathways converge at the level of effector caspase activation. ${ }^{34} \mathrm{Bcl}-2$ family members are highly conserved throughout evolution, with amino acid sequence homology concentrated within regions termed $\mathrm{BH}$ domains. On the basis of the presence of the $\mathrm{BH}$ domains and function, three major subgroups can be distinguished within the Bcl-2 family. Bcl-2, Bcl- $x_{\mathrm{L}}, \mathrm{Mcl}-1, \mathrm{~A} 1$ (BFL1) and Bcl-w share up to four $\mathrm{BH}$ domains (BH1-BH4), and these proteins are critical for cell survival, exerting celltype restricted, as well as overlapping anti-apoptotic functions. $^{32}$ The Bax/Bak-like proteins (possibly also including Bok) share remarkable structural similarity with their prosurvival relatives, but they are instead required for activation of the downstream (effector) stages of cellular demolition in apoptosis signalling. ${ }^{35,36}$ Upon activation, Bax/Bak mediate the mitochondrial outer membrane permeabilisation (MOMP), with consequent release of apoptogenic factors from mitochondria into the cytosol (cytochrome $c$, Smac/DIABLO (second mitochondria-derived activator of caspase/direct IAP binding protein with low $\mathrm{pl}$ )). These apoptogenic factors precipitate activation of the caspase cascade and cell-killing via Apaf-1-mediated activation of the initiator caspase, caspase-9, as well as by derepression of effector caspases by blocking their antagonist XIAP. ${ }^{35,36}$ The third subgroup of the $\mathrm{Bcl}-2$ family consists of the so-called $\mathrm{BH} 3-$ only proteins (Bad, Bik/Blk/Nbk, Hrk/DP5, Bid, Bim/Bod, Bmf, Noxa and Puma/Bbc3). These proteins share with each other, and the wider $\mathrm{Bcl}-2$ protein family, only the $\mathrm{BH} 3$ domain, which is required for their pro-apoptotic activity. $\mathrm{BH} 3$-only proteins are essential for initiation of apoptosis signalling, being activated transcriptionally and/or post-transcriptionally in a cell death stimulus-specific (and sometimes also cell type-specific) manner. ${ }^{32,37} \mathrm{BH} 3-$ only proteins differ in their specificity for binding pro-survival Bcl-2 family members: Bim, Puma and activated Bid, called tBid (so-called promiscuous binders), bind with high affinity to all pro-survival Bcl-2-like proteins,
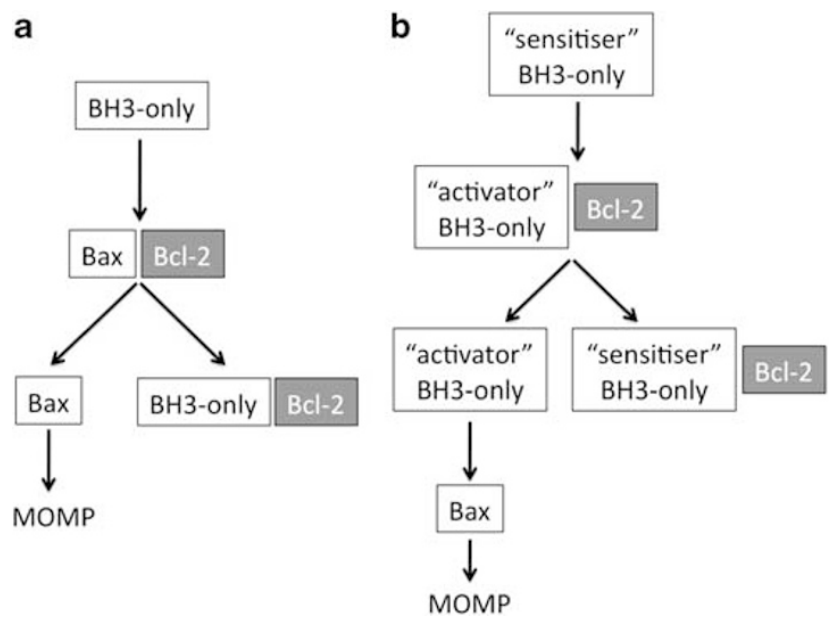

Figure 2 Models of how BH3-only proteins lead to Bax/Bak-activation. (a) In the indirect model, anti-apoptotic Bcl-2 family members neutralise (repress) Bax and Bak by direct interaction in healthy cells. Upon an apoptotic stimulus, one or several subsets of $\mathrm{BH} 3-$ only proteins become activated and compete with Bax-like proteins for the binding pocket on Bcl-2-like proteins, thereby derepressing Bax and/or Bak. (b) In the direct model, BH3-only proteins are divided into two subgroups: direct activators, including Bid and Bim (and possibly also Puma), which, besides neutralising Bcl-2-like proteins, can also directly activate Bax and/or Bak, and sensitisers, including Bad, Noxa, Harakiri, Bik and Bmf, which act only by neutralising Bcl-2-like proteins. The sensitisers thus act by lowering the threshold for Bax/Bak activation through activator $\mathrm{BH} 3$-only proteins. If the activators are already bound to Bcl-2-like proteins in healthy cells, sensitiser BH3-only proteins act as derepressors for activator $\mathrm{BH} 3$-only proteins 
whereas Bad binds only to $\mathrm{Bcl}-2$, Bcl- $\mathrm{x}_{\mathrm{L}}$ and $\mathrm{Bcl}-\mathrm{w}$, but not $\mathrm{Mcl}-$ 1 or $A 1$ and, conversely, Noxa only binds to Mcl-1 and A1. ${ }^{38,39}$ Accordingly, Bim, Puma and tBid are potent killers, but efficient cell killing by Bad can only be achieved when combined with Noxa or knockdown of $\mathrm{Mcl}-1 / \mathrm{A} 1 .^{38,39}$ It is firmly established that $\mathrm{BH} 3-o n l y$ proteins are essential for initiation of apoptosis signalling (e.g. see Bouillet et al. ${ }^{40}$ and Villunger et $a l^{41}$ ) and that they require Bax/Bak for cell killing, ${ }^{42,43}$ but the biochemical mechanisms by which $\mathrm{BH} 3$-only proteins activate Bax/Bak remain unclear (Figure 2). According to the direct model, the so-called activator $\mathrm{BH} 3$-only proteins, including Bim, tBid and possibly Puma, can directly bind to and activate Bax/Bak, whereas the so-called sensitiser BH3-only proteins (e.g. Bad, Noxa, Bik) act by binding to pro-survival Bcl-2-like proteins, thereby causing release of the activator $\mathrm{BH}$-only proteins. ${ }^{35,44}$ Conversely, the indirect model proposes that, in healthy cells, Bax/Bak are kept in check by the pro-survival $\mathrm{Bcl}-2$ family members and also proposes that for apoptotic death to occur, all pro-survival Bcl-2-like proteins present within a given cell need to be neutralised by $\mathrm{BH} 3-$ only proteins, thereby derepressing Bax/Bak. ${ }^{45}$

BH3-only proteins are tightly regulated at the transcriptional, as well as post-translational level. ${ }^{46}$ For example, puma $^{47,48}$ and noxa ${ }^{49}$ gene expression is directly upregulated by the transcription factor p53, a tumour suppressor that is disabled by mutation in $\sim 50 \%$ of all human cancers. ${ }^{50}$ Experiments with gene-targeted mice have identified the critical individual, as well as overlapping functions of $\mathrm{BH}$-only proteins. ${ }^{51}$ For example, Bim is essential for apoptosis induced by growth factor withdrawal, deregulated calcium flux ${ }^{40}$ and ER stress, ${ }^{52}$ and is critical for the developmentally programmed death of autoreactive $\mathrm{T}$ cells ${ }^{53}$ and B cells ${ }^{54}$ during their development in the thymus or bone marrow, respectively. Conversely, Puma and, to a lesser extent, Noxa are required for DNA damage-induced, p53-mediated apoptosis. ${ }^{41,55-57}$

\section{The Role of the BH3-only Protein Bid in DR-induced Apoptosis and Other Signalling Pathways}

Bid, unlike all other known BH3-only proteins, needs to be proteolysed by caspase-8 or other proteases to attain potent pro-apoptotic activity. ${ }^{23,24}$ Once cleaved, tBid translocates to the mitochondrial outer membrane, facilitated by its interaction with $\mathrm{MTCH} 2 / \mathrm{MIMP},{ }^{58}$ where it leads to the activation of Bax/Bak and consequently MOMP, caspase activation and cell demolition. Processing of Bid into tBid is mainly mediated by caspase-8, the apical caspase in the DR apoptotic pathway. ${ }^{23,24}$ Activation of Bid, therefore, constitutes a process for crosstalk between the DR and the Bcl-2-regulated apoptotic pathways, allowing amplification of the caspase cascade to ensure efficient cell demolition (Figure 1). Experiments with diverse cell types from bid $^{-1}$ mice have shown that Bid is critical for Fas-induced apoptosis in certain cell types (so-called type 2 cells), including hepatocytes and pancreatic $\beta$-cells, but dispensable in others (so-called type 1 cells), such as thymocytes or mature $\mathrm{T}$ cells. ${ }^{59-61}$ This indicates that amplification of the caspase cascade is critical for Fas-induced apoptosis in the former, but not the latter cell types.
The tBid-mediated crosstalk to the Bcl-2-regulated apoptotic pathway amplifies the pro-apoptotic signal through activation of Bax/Bak, consequent induction of MOMP with release of apoptogenic factors, including cytochrome $c$ and the IAP antagonists (Smac/DIABLO, Omi/Htra2), ultimately causing cell demolition by the enhanced caspase cascade. The precise contribution of mitochondrial factors to Fasinduced apoptosis is still not fully understood. Remarkably, a mutation in cytochrome $c$ that interferes with its interaction with the caspase- 9 adaptor Apaf-1 and therefore blocks apoptosome formation provided no protection against Fasinduced hepatocyte killing and consequent fatal hepatitis. ${ }^{62}$ Conversely, overexpression of anti-apoptotic Bcl-2 family members $^{63}$ or combined loss of Bax/Bak ${ }^{64,65}$ conferred (at least partial) protection from Fas-induced apoptosis in type 2 cells (e.g. hepatocytes), but not in type 1-like cells (e.g. thymocytes). ${ }^{33,66}$ This indicates that activation of Bax/ Bak constitutes the point of no return in Fas-induced killing of type 2 cells that is dependent on Bid-mediated amplification via the Bcl-2-regulated apoptotic pathway, whereas caspase9 activity is not required. Thus, disruption of mitochondrial outer membrane integrity per se or mitochondrial release of antagonists of XIAP (e.g. Smac/DIABLO) that de-repress effector caspases must be critical for Fas-induced killing of type 2 cells.

Interestingly, it is possible to override the need for the mitochondrial apoptotic pathway for Fas-mediated killing of type 2 cells by using a very strong Fas-agonist, such as a hexameric form of FasL (called MegaFasL, developed by Juerg Tschopp's laboratory). ${ }^{67}$ For example, in mice deficient for Bid, an injection of MegaFasL induced killing of parenchymal and possibly non-parenchymal cells within the liver, thereby driving hepatocellular demise and death of experimental animals, although the fatal outcome was still clearly delayed compared with wild-type mice. ${ }^{67}$ This finding demonstrates that high level caspase-8-mediated activation of effector caspases, achieved by extensive Fas crosslinking on the cell surface, can bypass the need for the Bid>Bax/ Bak > MOMP amplification loop in type 2 cells, and this is consistent with the notion that XIAP acting as an inhibitor of effector caspases can regulate this process (see below).

Experiments with bid $^{-1-}$ mice have shown that caspase-8mediated proteolytic activation of Bid is also critical for hepatocyte killing and fatal hepatitis mediated by TNF $>$ TNF-R1 stimulation, for example, elicited by injection with LPS plus the hepatocyte-specific sensitiser GalN (to block anti-apoptotic signalling from TNF-R1, which requires de novo gene transcription). ${ }^{68,69}$ In this pathological scenario, but not in FasL-induced liver destruction, $\mathrm{tBid}$ cooperates with the $\mathrm{BH}$ only protein $\mathrm{Bim}^{70}$, which is activated by TNF-R1 in a caspase-8-independent manner, to kill hepatocytes. ${ }^{69}$

Proteases other than caspase- 8 have been reported to cleave and convert Bid into tBid (or similarly active truncated forms of $\mathrm{Bid}$ ); they include granzyme $\mathrm{B},{ }^{71}$ lysosomal cathepsins $^{72}$ and calpain, ${ }^{73,74}$ although unlike for caspase8-mediated cleavage of Bid in Fas-, DR-4/-5- or TNF-R1induced apoptosis, the physiological relevance of these processes for Bid proteolysis are presently still unclear. The functions of full-length Bid are only poorly understood, but there are reports showing a pro-apoptotic activity of full-length 
Bid on mitochondria. ${ }^{75,76}$ Moreover, full-length Bid has very recently been reported to be critical for a non-cell deathrelated process, namely the production of pro-inflammatory cytokines. $^{77}$

\section{XIAP and Type 1 versus Type 2 Fas-induced Apoptosis Signalling}

XIAP can inhibit apoptosis by binding and thereby inactivating certain caspases, including the initiator caspase- 9 and the effector caspases ( -3 and -7$).{ }^{78,79}$ XIAP stands out of the mammalian IAP protein family, because it is the only member capable of blocking active caspases. The binding affinity of XIAP to caspases ( -3 and -7 ) is very strong, whereas binding to the initiator caspase- 9 is of considerably lower affinity and binding to the initiator caspase- 8 is undetectable. ${ }^{80}$ This affinity profile places XIAP as an inhibitor of the common effector phase of apoptosis, hence acting downstream of the Fas death-receptor stimulation and the receptor proximal signalling events within the DISC, including FADD-mediated recruitment and activation of caspase-8 (Figure 1). XIAP contains three baculovirus internal repeat (BIR) domains that make up most of the amino terminal portion of the protein. Interestingly, the BIR domains are functionally distinct. BIR1 facilitates binding of XIAP to the TGF $\beta$-activated kinase binding protein 1 (TAB1), thereby mediating activation of NF$\kappa \mathrm{B} .{ }^{81}$ In contrast, the BIR2/BIR3 domains mediate binding of XIAP to proteins harbouring an IAP-binding motif, including active caspases. This interaction is facilitated by a deep hydrophobic peptide-binding groove within the BIR2 and BIR3. ${ }^{80,82-84}$ In addition, the linker region located adjacent to the BIR2 domain also participates in the binding of XIAP to the effector caspases (-3 and -7 ) by inserting a steric hindrance into the active site pocket of these proteases. ${ }^{85,86}$

The function of XIAP in death-receptor signalling has classically been associated with the presence of BIR domains and the direct inhibitory interaction with effector caspases. ${ }^{87}$ However, more recently its has been revealed that XIAP possesses E3 ligase activity and that, in response to ligation of at least certain DRs, XIAP is capable of targeting some signalling proteins for ubiquitylation. ${ }^{88}$ These non-BIR domain-mediated functions of XIAP have proven to be more complex than initially anticipated, and we still do not fully understand which signalling pathways are regulated by XIAP by its RING domain-dependent E3 ligase activity. ${ }^{89}$ The RING domain is located at the carboxyl terminus of XIAP and mediates ubiquitylation not only of target proteins, but also XIAP itself, a critical determinant of XIAP stability in vivo $^{90}$ Accordingly, experimental mice expressing a mutant of XIAP that lacks the RING domain express abnormally high levels of XIAP protein in their cells. ${ }^{90}$ Unexpectedly, the enhanced stability of $X \mathrm{AP}^{\triangle \mathrm{RING}}$ did not afford hepatocytes from these mice with enhanced protection from Fas-induced apoptosis. ${ }^{90}$ Even more surprisingly, the $\mathrm{XIAP}^{\Delta \mathrm{RING}}$ mutant protein exhibited abnormally reduced anti-apoptotic activity in murine embryonic fibroblasts exposed to $T N F \alpha$, indicating that anti-apoptotic activity as well as protein stability of XIAP is determined (in part) by its RING domain. ${ }^{90}$ Interestingly, the notion that the RING domain of XIAP might be critical for its ability to regulate cell death stemmed from experiments in $D$. melanogaster. ${ }^{91}$ The fly IAP homologue DIAP1 is capable of ubiquitylating caspases and thereby exerts an anti-apoptotic effect that is independent of direct blockade of the catalytic site within these proteases. The DIAP1-mediated ubiqutination inactivates the $D$. melanogaster caspases drICE and DCP1 by a mechanism that is still not fully understood, but might involve proteasomal degradation. ${ }^{92}$

Studies with gene-targeted ('knock-out') as well as transgenic mice were employed to determine the function of XIAP. Enforced overexpression of XIAP within the T-lymphocyte lineage under control of the lck promoter revealed that XIAP could inhibit Fas-induced apoptosis in non-transformed cells, although it is noteworthy that the extent of protection was relatively minor, particularly when $T$ lymphocytes were challenged with agonistic antibodies to Fas in vivo. ${ }^{93}$ Initial analyses showed that XIAP-deficient mice were largely normal, but only a limited number of cell types were studied and mice or cells derived from them were only challenged by a restricted set of stimuli. ${ }^{94,95}$ As described above, the mechanisms of Fas-induced apoptosis differ substantially between different cell types, both in vitro and in vivo. Once caspase- 8 is activated and processed in response to Fas ligation, it can proteolyse its specific substrates in the cytosol. Its most prominent substrates include the zymogens of effector caspases $\left(-3\right.$ and $\left.-7 ;^{25-27}\right)$ and $\mathrm{Bid},{ }^{23,24}$ both of which are activated by proteolytic cleavage. Cells sensitive to Fas-induced apoptosis can roughly be classified into two groups (Figure 1): in so-called type 1 cells (e.g. thymocytes), caspase-8-mediated activation of effector caspases (-3 and -7$)$ is efficient and suffices for cell killing without the need for caspase cascade amplification through Bid-mediated engagement of the Bcl-2-regulated apoptotic pathway; on the other hand, in so-called type 2 cells (e.g. hepatocytes), this amplification mechanism is critical for cell killing. It appears likely that the type 1 versus type 2 discrimination will turn out not to be a black or white categorisation, but rather represent the extremes of a spectrum of responses to Fas ligation occupied by different cell types.

Regardless, it has been proposed that the differences between type 1 and type 2 cells relate to the extent of effector caspase activation that can be achieved, and perhaps the abundance of their substrates that need to be proteolysed to achieve cellular demise. ${ }^{59}$ The extent of effector caspase activation is determined by, amongst other factors, the levels of Fas on the cell surface, the efficiency of DISC formation with recruitment and activation of caspase-8, the efficiency of proteolytic activation of $\mathrm{Bid}$, induction of MOMP with release of apoptogenic factors and, conversely, the levels of inhibitors of these processes, namely c-FLIP and XIAP.

So, what do we know about the molecular factors involved in the decision whether a Fas-sensitive cell behaves more like type 1 or more like type 2 ? Initially it was thought that type 1 -like signalling solely depended on the cell's ability to rapidly form large amounts of DISC, resulting in high concentration of active caspase-8, which could then directly activate effector caspases. Type 2-like signalling, on the other hand, was correlated with a much weaker and slower ability to from the DISC and activate caspase-8, which could only trigger the effector phase of cell death by engaging the tBid-mediated 
mitochondrial amplification step. ${ }^{96}$ It was therefore believed that events at the plasma membrane discriminate between type 1 versus type 2 signalling. ${ }^{97}$ However, the situation seems to be more complex. For one part, tBid is very potent in triggering MOMP; in other words, even at low caspase-8 activity and relatively low levels of Bid proteolysis, the resulting tBid may well be sufficient to trigger full MOMP with consequent efficient activation of downstream events in the Bcl-2-regulated apoptotic pathway. For the other part, increasing caspase-8 activity, for example by downregulating c-FLIP, does not automatically convert type 2 into type 1 cells. ${ }^{98}$ This can probably be attributed to the action of XIAP, ${ }^{99}$ which can directly bind and inhibit the effector caspases
(-3 and -7; and also active caspase-9, although with much weaker affinity). ${ }^{79}$ High levels of XIAP would be predicted to attenuate Fas-induced apoptosis signalling at a much more downstream stage, targeting and blocking processed effector caspases. During MOMP, apoptogenic proteins are released from the mitochondrial intermembrane space, including the IAP antagonists Smac/DIABLO ${ }^{100,101}$ and Omi/HtrA2, ${ }^{102,103}$ which target XIAP among others, resulting in the derepression of active caspases -3, -7 (and possibly also caspase-9). Accordingly, XIAP was identified as a crucial discriminator between type 1 and type 2 Fas-induced apoptosis. ${ }^{59,104}$ Remarkably, although loss of Bid renders mice resistant to FasL-induced hepatocyte apoptosis and fatal hepatitis,

Table 1 Currently recruiting clinical trials using (a) IAP antagonists (also called SMAC-mimetics) as interventional drug and (b) FAS (CD95/APO-1)-activating compounds as interventional drug (current as of 04.08.2011 from the US National Institutes of Health; www.clinicaltrials.gov)

\begin{tabular}{|c|c|c|c|c|}
\hline Company & Compound & Condition & Stage & NCT No. \\
\hline \multicolumn{5}{|l|}{ (a) } \\
\hline \multirow[t]{2}{*}{ Ascenta Therapeutics (Malvern, PA, USA) } & AT-406 & Solid cancer, lymphoma & I & NCT01078649 \\
\hline & AT-406 & AML & i & NCT01265199 \\
\hline Novartis Pharmaceuticals (Basel, Switzerland) & LCL-161 & Solid cancer & i & NCT01240655 \\
\hline \multirow{2}{*}{ Human Genome Sciences (Rockville, MD, USA) } & HGS1029 & Solid cancer & I & NCT01013818 \\
\hline & HGS1029 & Lymphoma & i & NCT00708006 \\
\hline Tetralogics (Malvern, PA, USA) & TL32711 & Solid cancer or lymphoma & i & NCT00993239 \\
\hline \multirow[t]{2}{*}{ Genentech (South San Francisco, CA, USA) } & GDC-0917 & Solid cancer & i & NCT01226277 \\
\hline & TL32711 & Solid cancer & $\mathrm{lb} / \mathrm{Ila}$ & NCT01188499 \\
\hline \multicolumn{5}{|l|}{ (b) } \\
\hline TopoTarget A/S (Copenhagen, Denmark) & APO010 & Solid cancer & 1 & NCT00437736 \\
\hline
\end{tabular}

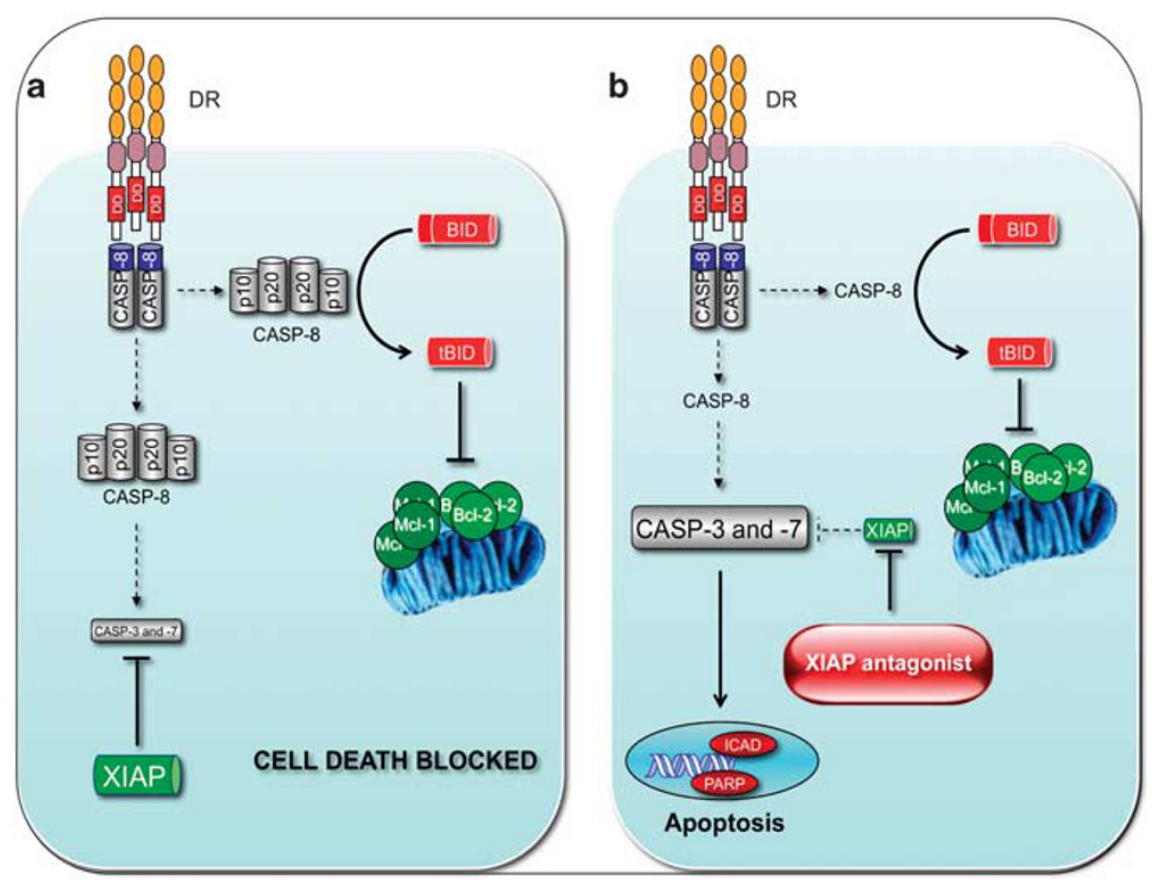

Figure 3 Sensitisation of type 2 cancer cells towards DR-induced killing by synthetic IAP antagonists. (a) This image represents a type-2 cancer cell that, through overexpression of anti-apoptotic Bcl-2 proteins (e.g. Bcl-2 or Mcl-1) and/or XIAP, has become highly resistant towards FasL- or TRAIL-induced apoptosis. (b) Addition of an IAP-antagonistic small molecular Smac-mimetic, ideally an XIAP-selective inhibitor to minimise side effects, uncouples the DR-induced apoptotic pathway from its mandatory crosstalk to the mitochondrial apoptotic pathway, thereby sensitising the cancer cells towards FasL-, TRAIL- or TNF-induced killing. Combination therapy with additional standard chemotherapeutic drugs, or direct targeting of anti-apoptotic $\mathrm{Bcl}-2$ proteins by $\mathrm{BH} 3$ mimetics, thereby triggering MOMP, might further sensitise the cancer cell to undergo apoptosis 
concomitant loss of XIAP (in $\mathrm{bid}^{-1-}$ xiap $^{-1-}$ mice) fully restored sensitivity. ${ }^{59}$ Loss of XIAP alone (on a bid ${ }^{+/+}$background) significantly (albeit to a relatively minor extent) accelerated FasL-induced hepatocyte apoptosis and fatal hepatitis, but had no impact on the rate of FasL-induced apoptosis in thymocytes. ${ }^{59}$ This indicates that the XIAP-imposed brake on effector caspases is critical for the regulation in Fas-induced apoptosis signalling in type 2, but not type 1 cells, consistent with the notion that the magnitude of the caspase cascade is limiting in the former. In conclusion, whether a cell behaves like type 1 or like type 2 is thus likely to depend not on the levels of a single protein but rather on the ratio between processed effector caspases (-3 and -7$)$, a more or less direct consequence of DISC formation and caspase-8 activation, and the levels of free XIAP. Given the complex posttranslational regulation of XIAP stability and activity, ${ }^{90}$ this ratio is likely to be subject to a large extent of variation as a consequence of a broad range of cell stimuli, even within the same cell type, and would thus be difficult to predict.

\section{Therapeutic Implications}

Due to their profound liver toxicity (and maybe toxicity in other tissues as well), potent Fas agonists, such as highly aggregated FasL ${ }^{16,60}$ or anti-Fas antibodies, ${ }^{105}$ are unsuited for therapeutic applications, particularly if one aimed to combine Fas-activation with IAP antagonists, which further increase the sensitivity of hepatocytes towards Fas-induced killing. $^{59}$ It is, however, noteworthy that less potent Fas agonists (some of them developed by Juerg Tschopp), that do not cause unacceptable collateral damage, may find utility in cancer therapy (see Table 1). ${ }^{106}$ Moreover, the broad concept of type 1/type 2 apoptosis signalling, initially discovered for Fas-induced cell killing, is also pertinent to DR-induced apoptosis activated by TRAIL, ${ }^{107-110}$ and (to a certain extent) by $\mathrm{TNF}^{69}$, ligands that are used and/or being developed for cancer therapy. ${ }^{111}$

Importantly, with respect to the use of activators of the DR apoptotic pathway for cancer therapy, many tumour cells, in particular lymphomas and leukaemias, behave like type 2 cells $^{96}$ and many of them are relatively resistant to FasL-, TNF- or TRAIL-induced killing, most likely as a consequence of the high levels of $\mathrm{Bcl}-2, \mathrm{Mcl}-1, \mathrm{Bcl}-\mathrm{x}_{\mathrm{L}}$ and/or XIAP that they express. ${ }^{111}$ Breaking the resistance towards FasL-, TNF- or TRAIL-induced killing of malignant cells might therefore aid in the development of more efficacious regimes for the treatment of certain cancers. The blockade of effector caspases by XIAP in normal as well as transformed cells is blocked physiologically by IAP antagonists, such as Smac/DIABLO, ${ }^{100,101}$ and such de-repression of effector caspases can also be achieved by small molecule Smac/DIABLO mimetics. Accordingly, there is increasing experimental evidence that small molecule IAP antagonists can sensitise resistant cancer cells towards TRAIL and/or TNF-induced killing, either given as single agents, or in combination with classical chemotherapeutic drugs (Figure 3). ${ }^{112-116}$ The IAP antagonists available today target multiple members of the IAP family, including cIAP1, CIAP2 and XIAP (see Table 1 for an overview of current clinical trials using IAP antagonists). ${ }^{117}$ Given the role of CIAP1 and CIAP2 in the regulation of proximal events in TNF-R1 signalling, ${ }^{117,118}$ antagonists that are highly specific for XIAP may be even better suited than broad spectrum IAP inhibitors for cancer therapy.

\section{Conflict of Interest}

The authors declare no conflict of interest.

Acknowledgements. We dedicate this review to the memory of Juerg Tschopp, wonderfully generous human being and outstanding scientist, who left behind not only important scientific discoveries, but also, importantly, the novel treatments for several inflammatory diseases. He will be solely missed. We thank all the present and the past members of the apoptosis research programs at WEHI, particularly Drs JM Adams, S Cory, D Vaux, J Silke, D Huang, P Colman, P Bouillet, R Kluck and C Scott, for their outstanding contributions and stimulating discussions. Research in our laboratories is supported by fellowships and grants from the Australian NHMRC (257502, 461299), NIH (CA 043540), Leukemia and Lymphoma Society (LLS SCOR 7413), JDRF/NHMRC (466658), the Max-Eder Program grant from the Mildred Scheel-Stiftung/ Deutsche Krebshilfe, the Novartis Foundation for Medicine and Biology, and the Swiss National Science Foundation (PP00A-119203).

1. Aggarwal BB. Signalling pathways of the TNF superfamily: a double-edged sword. Nat Rev Immunol 2003; 3: 745-756.

2. Strasser A, Jost PJ, Nagata $S$. The many roles of FAS receptor signaling in the immune system. Immunity 2009; 30: 180-192.

3. Holler N, Zaru R, Micheau O, Thome M, Attinger A, Valitutti S et al. Fas triggers an alternative, caspase-8-independent cell death pathway using the kinase RIP as effector molecule. Nat Immunol 2000; 1: 489-495.

4. Vanden Berghe T, van Loo G, Saelens X, Van Gurp M, Brouckaert G, Kalai M et al. Differential signaling to apoptotic and necrotic cell death by Fas-associated death domain protein FADD. J Biol Chem 2004; 279: 7925-7933.

5. Geserick P, Hupe M, Moulin M, Wong WW, Feoktistova M, Kellert B et al. Cellular IAPs inhibit a cryptic CD95-induced cell death by limiting RIP1 kinase recruitment. J Cell Biol 2009; 187: 1037-1054.

6. Kroemer G, Galluzzi L, Vandenabeele P, Abrams J, Alnemri ES, Baehrecke EH et al. Classification of cell death: recommendations of the Nomenclature Committee on Cell Death 2009. Cell Death Differ 2009; 16: 3-11.

7. Peter ME, Budd RC, Desbarats J, Hedrick SM, Hueber AO, Newell MK et al. The CD95 receptor: apoptosis revisited. Cell 2007; 129: 447-450.

8. Nagata S. Fas ligand-induced apoptosis. Ann Rev Genet 1999; 33: 29-55.

9. Allison J, Georgiou HM, Strasser A, Vaux DL. Transgenic expression of CD95 ligand on islet $\beta$ cells induces a granulocytic infiltration, but does not confer immune privilege upon islet allografts. Proc Nat Acad Sci USA 1997; 94: 3943-3947.

10. Schulte M, Reiss K, Lettau M, Maretzky T, Ludwig A, Hartmann D et al. ADAM10 regulates FasL cell surface expression and modulates FasL-induced cytotoxicity and activation-induced cell death. Cell Death Differ 2007; 14: 1040-1049.

11. O'Reilly L, Tai L, Lee L, Kruse EA, Grabow S, Fairlie WD et al. Membrane-bound Fas ligand only is essential for Fas-induced apoptosis. Nature 2009; 461: 659-663.

12. Siegel RM, Frederiksen JK, Zacharias DA, Chan FK, Johnson M, Lynch D et al. Fas preassociation required for apoptosis signaling and dominant inhibition by pathogenic mutations. Science 2000; 288: 2354-2357.

13. Kennedy NJ, Kataoka T, Tschopp J, Budd RC. Caspase activation is required for T cell proliferation. J Exp Med 1999; 190: 1891-1896.

14. Schneider P, Holler N, Bodmer JL, Hahne M, Frei K, Fontana A et al. Conversion of membrane-bound Fas(CD95) ligand to its soluble form is associated with downregulation of its proapoptotic activity and loss of liver toxicity. J Exp Med 1998; 187: 1205-1213.

15. Tanaka M, Itai T, Adachi M, Nagata S. Downregulation of Fas ligand by shedding. Nat Med 1998; 4: 31-36.

16. Huang DC, Hahne M, Schroeter M, Frei K, Fontana A, Villunger A et al. Activation of Fas by FasL induces apoptosis by a mechanism that cannot be blocked by $\mathrm{Bcl}-2$ or $\mathrm{Bcl}-\mathrm{x}_{\mathrm{L}}$. Proc Natl Acad Sci USA 1999; 96: 14871-14876.

17. Hohlbaum AM, Moe S, Marshak-Rothstein A. Opposing effects of transmembrane and soluble Fas ligand expression on inflammation and tumor cell survival. J Exp Med 2000; 191: $1209-1219$

18. Kischkel FC, Hellbardt S, Behrmann I, Germer M, Pawlita M, Krammer PH et al. Cytotoxicity-dependent APO-1 (Fas/CD95) - associated proteins form a death-inducing signaling complex (DISC) with the receptor. EMBO J 1995; 14: 5579-5588. 
19. Boldin MP, Varfolomeev EE, Pancer Z, Mett IL, Camonis JH, Wallach D. A novel protein that interacts with the death domain of Fas/APO1 contains a sequence motif related to the death domain. J Biol Chem 1995; 270: 7795-7798.

20. Chinnaiyan AM, O'Rourke K, Tewari M, Dixit VM. FADD, a novel death domain-containing protein, interacts with the death domain of Fas and initiates apoptosis. Cell 1995; 81 $505-512$.

21. Muzio M, Chinnaiyan AM, Kischkel FC, O'Rourke K, Shevchenko A, Ni J et al. FLICE, a novel FADD homologous ICE/CED-3-like protease, is recruited to the CD95 (Fas/Apo-1) death-inducing signaling complex. Cell 1996; 85: 817-827.

22. Boatright KM, Renatus M, Scott FL, Sperandio S, Shin H, Pedersen IM et al. A unified model for apical caspase activation. Mol Cell 2003; 11: 529-541.

23. Li H, Zhu H, Xu C-J, Yuan J. Cleavage of BID by caspase 8 mediates the mitochondrial damage in the Fas pathway of apoptosis. Cell 1998; 94: 491-501.

24. Luo X, Budihardjo I, Zou H, Slaughter C, Wang X. Bid, a Bcl-2 interacting protein, mediates cytochrome $\mathrm{c}$ release from mitochondria in response to activation of cell surface death receptors. Cell 1998; 94: 481-490.

25. Fernandes-Alnemri T, Armstrong RC, Krebs J, Srinivasula SM, Wang L, Bullrich F et al. In vitro activation of CPP32 and Mch3 by Mch4, a novel human apoptotic cysteine protease containing two FADD-like domains. Proc Nat Acad Sci USA 1996; 93 7464-7469.

26. Stennicke $H R$, Jürgensmeier $J M$, Shin $H$, Deveraux $Q$, Wolf $B B$, Yang $X$ et al. Pro-caspase-3 is a major physiologic target of caspase-8. J Biol Chem 1998; 273 27084-27090.

27. Srinivasula SM, Ahmad M, Fernandes-Alnemri T, Litwack G, Alnemri ES. Molecular ordering of the Fas-apoptotic pathway: the Fas/APO-1 protease Mch5 is a CrmAinhibitable protease that activates multiple Ced-3/ICE-like cysteine proteases. Proc Nat Acad Sci USA 1996; 93: 14486-14491.

28. Irmler M, Thome M, Hahne M, Schneider P, Hofmann K, Steiner V et al. Inhibition of death receptor signals by cellular FLIP. Nature 1997; 388: 190-194.

29. Ueffing N, Keil E, Freund C, Kuhne R, Schulze-Osthoff K, Schmitz I. Mutational analyses of c-FLIPR, the only murine short FLIP isoform, reveal requirements for DISC recruitment. Cell Death Differ 2008; 15: 773-782.

30. Kirchhoff S, Müller WW, Krueger A, Schmitz I, Krammer PH. TCR-mediated up-regulation of c-FLIP short correlates with resistance toward CD95-mediated apoptosis by blocking death-inducing signaling complex activity. J Immunol 2000; 165: 6293-6300.

31. Thome M, Schneider P, Hofmann K, Fickenscher H, Meinl E, Neipel F et al. Viral FLICEinhibitory proteins (FLIPs) prevent apoptosis induced by death receptors. Nature 1997; 386: 517-521.

32. Youle RJ, Strasser A. The BCL-2 protein family: opposing activities that mediate cell death. Nat Rev Mol Cell Biol 2008; 9: 47-59.

33. Strasser A, Harris AW, Huang DC, Krammer PH, Cory S. Bcl-2 and Fas/APO-1 regulate distinct pathways to lymphocyte apoptosis. EMBO J 1995; 14: 6136-6147.

34. Strasser A, O'Connor L, Dixit VM. Apoptosis signaling. Ann Rev Biochem 2000; 69: 217-245.

35. Chipuk JE, Green DR. How do BCL-2 proteins induce mitochondrial outer membrane permeabilization? Trends Cell Biol 2008; 18: 157-164.

36. Hengartner MO. The biochemistry of apoptosis. Nature 2000; 407: 770-776.

37. Huang DC, Strasser A. BH3-Only proteins-essential initiators of apoptotic cell death. Cell 2000; 103: 839-842.

38. Chen L, Willis SN, Wei A, Smith BJ, Fletcher Jl, Hinds MG et al. Differential targeting of prosurvival Bcl-2 proteins by their $\mathrm{BH} 3$-only ligands allows complementary apoptotic function. Mol Cell 2005; 17: 393-403.

39. Kuwana T, Bouchier-Hayes L, Chipuk JE, Bonzon C, Sullivan BA, Green DR et al. BH3 domains of BH3-only proteins differentially regulate Bax-mediated mitochondrial membrane permeabilization both directly and indirectly. Mol Cell 2005; 17: 525-535.

40. Bouillet $\mathrm{P}$, Metcalf D, Huang DC, Tarlinton DM, Kay TW, Kontgen F et al. Proapoptotic Bcl-2 relative Bim required for certain apoptotic responses, leukocyte homeostasis, and to preclude autoimmunity. Science 1999; 286: 1735-1738.

41. Villunger A, Michalak EM, Coultas L, Mullauer F, Bock G, Ausserlechner MJ et al. p53- and drug-induced apoptotic responses mediated by $\mathrm{BH}$-only proteins puma and noxa. Science 2003; 302: 1036-1038

42. Zong WX, Lindsten T, Ross AJ, MacGregor GR, Thompson CB. BH3-only proteins that bind pro-survival $\mathrm{Bcl}-2$ family members fail to induce apoptosis in the absence of $\mathrm{Bax}$ and Bak. Genes Dev 2001; 15: 1481-1486.

43. Cheng EH, Wei MC, Weiler S, Flavell RA, Mak TW, Lindsten T et al. BCL-2, BCL-X sequester $\mathrm{BH} 3$ domain-only molecules preventing BAX- and BAK-mediated mitochondrial apoptosis. Mol Cell 2001; 8: 705-711.

44. Letai A, Bassik M, Walensky L, Sorcinelli M, Weiler S, Korsmeyer S. Distinct BH3 domains either sensitize or activate mitochondrial apoptosis, serving as prototype cance therapeutics. Cancer Cell 2002; 2: 183-192.

45. Willis SN, Fletcher Jl, Kaufmann T, van Delft MF, Chen L, Czabotar PE et al. Apoptosis initiated when $\mathrm{BH} 3$ ligands engage multiple Bcl-2 homologs, not Bax or Bak. Science 2007; 315: 856-859.

46. Puthalakath $H$, Strasser A. Keeping killers on a tight leash: transcriptional and posttranslational control of the pro-apoptotic activity of $\mathrm{BH} 3$-only proteins. Cell Death Diffe 2002; 9: 505-512.

47. Nakano K, Vousden KH. PUMA, a novel proapoptotic gene, is induced by p53. Mol Cell 2001; 7: 683-694
48. Yu J, Zhang L, Hwang PM, Kinzler KW, Vogelstein B. PUMA induces the rapid apoptosis of colorectal cancer cells. Mol Cell 2001; 7: 673-682.

49. Oda E, Ohki R, Murasawa H, Nemoto J, Shibue T, Yamashita T et al. Noxa, a BH3-only member of the bcl-2 family and candidate mediator of p53-induced apoptosis. Science 2000; 288: 1053-1058

50. Vousden KH, Lane DP. p53 in health and disease. Nat Rev Mol Cell Biol 2007; 8: 275-283.

51. Huang DCS, Strasser A. BH3-only proteins - essential initiators of apoptotic cell death. Cell 2000; 103: 839-842.

52. Puthalakath H, O'Reilly LA, Gunn P, Lee L, Kelly PN, Huntington ND et al. ER stress triggers apoptosis by activating BH3-only protein Bim. Cell 2007; 129: 1337-1349.

53. Bouillet P, Purton JF, Godfrey DI, Zhang L-C, Coultas L, Puthalakath $\mathrm{H}$ et al. BH3-only $\mathrm{Bcl}-2$ family member Bim is required for apoptosis of autoreactive thymocytes. Nature 2002; 415: 922-926.

54. Enders A, Bouillet $P$, Puthalakath $H, X u Y$, Tarlinton DM, Strasser A. Loss of the proapoptotic BH3-only Bcl-2 family member Bim inhibits BCR stimulation-induced apoptosis and deletion of autoreactive B cells. J Exp Med 2003; 198: 1119-1126.

55. Jeffers JR, Parganas E, Lee $Y$, Yang C, Wang J, Brennan J et al. Puma is an essential mediator of p53-dependent and -independent apoptotic pathways. Cancer Cell 2003; 4: 321-328

56. Shibue T, Takeda K, Oda E, Tanaka H, Murasawa H, Takaoka A et al. Integral role of Noxa in p53-mediated apoptotic response. Genes Dev 2003; 17: 2233-2238.

57. Michalak EM, Villunger A, Adams JM, Strasser A. In several cell types tumour suppressor p53 induces apoptosis largely via Puma but Noxa can contribute. Cell Death Differ 2008; 15: 1019-1029.

58. Zaltsman Y, Shachnai L, Yivgi-Ohana N, Schwarz M, Maryanovich M, Houtkooper RH et al. MTCH2/MIMP is a major facilitator of tBID recruitment to mitochondria. Nat Cell BiO 2010; 12: 553-562.

59. Jost PJ, Grabow S, Gray D, McKenzie MD, Nachbur U, Huang DC et al. XIAP discriminates between type I and type II FAS-induced apoptosis. Nature 2009; 460: 1035-1039.

60. Kaufmann T, Tai L, Ekert PG, Huang DC, Norris F, Lindemann RK et al. The BH3-only protein bid is dispensable for DNA damage- and replicative stress-induced apoptosis or cell-cycle arrest. Cell 2007; 129: 423-433.

61. Yin X-M, Wang K, Gross A, Zhao Y, Zinkel S, Klocke B et al. Bid-deficient mice are resistant to Fas-induced hepatocellular apoptosis. Nature 1999; 400: 886-891.

62. Hao Z, Duncan GS, Chang CC, Elia A, Fang M, Wakeham A et al. Specific ablation of the apoptotic functions of cytochrome $\mathrm{C}$ reveals a differential requirement for cytochrome $\mathrm{C}$ and Apaf-1 in apoptosis. Cell 2005; 121: 579-591.

63. Rodriguez I, Matsuura K, Khatib K, Reed JC, Nagata S, Vassalli P. A bcl-2 transgene expressed in hepatocytes protects mice from fulminant liver destruction but not from rapid death induced by anti-Fas antibody injection. J Exp Med 1996; 183: 1031-1036.

64. Wei MC, Zong WX, Cheng EH, Lindsten T, Panoutsakopoulou V, Ross AJ et al. Proapoptotic $B A X$ and BAK: a requisite gateway to mitochondrial dysfunction and death. Science 2001; 292: 727-730.

65. Hikita H, Takehara T, Kodama T, Shimizu S, Shigekawa M, Hosui A et al. Delayed-onset caspase-dependent massive hepatocyte apoptosis upon fas activation in bak/baxdeficient mice. Hepatology 2011; 54: 240-251.

66. Lindsten T, Ross AJ, King A, Zong W, Rathmell JC, Shiels HA et al. The combined functions of proapoptotic Bcl-2 family members Bak and Bax are essential for normal development of multiple tissues. Mol Cell 2000; 6: 1389-1399.

67. Schungel S, Buitrago-Molina LE, Nalapareddy PD, Lebofsky M, Manns MP, Jaeschke H et al. The strength of the Fas ligand signal determines whether hepatocytes act as type 1 or type 2 cells in murine livers. Hepatology 2009; 50: 1558-1566.

68. Zhao Y, Li S, Childs EE, Kuharsky DK, Yin XM. Activation of pro-death Bcl-2 family proteins and mitochondria apoptosis pathway in tumor necrosis factor-alpha-induced liver injury. J Biol Chem 2001; 276: 27432-27440.

69. Kaufmann T, Jost PJ, Pellegrini M, Puthalakath H, Gugasyan R, Gerondakis S et al. Fatal hepatitis mediated by tumor necrosis factor TNFalpha requires caspase- 8 and involves the BH3-only proteins Bid and Bim. Immunity 2009; 30: 56-66.

70. O'Connor L, Strasser A, O'Reilly LA, Hausmann G, Adams JM, Cory S et al. Bim: a nove member of the Bcl-2 family that promotes apoptosis. EMBO J 1998; 17: 384-395.

71. Sutton VR, Davis JE, Cancilla M, Johnstone RW, Ruefli AA, Sedelies K et al. Initiation of apoptosis by granzyme $B$ requires direct cleavage of Bid, but not direct granzyme B-mediated caspase activation. J Exp Med 2000; 192: 1403-1414.

72. Cirman T, Oresic K, Mazovec GD, Turk V, Reed JC, Myers RM et al. Selective disruption of lysosomes in HeLa cells triggers apoptosis mediated by cleavage of Bid by multiple papain-like lysosomal cathepsins. J Biol Chem 2004; 279: 3578-3587.

73. Chen M, He H, Zhan S, Krajewski S, Reed JC, Gottlieb RA. Bid is cleaved by calpain to an active fragment in vitro and during myocardial ischemia/reperfusion. J Biol Chem 2001; 276: 30724-30728.

74. Mandic A, Viktorsson K, Strandberg L, Heiden T, Hansson J, Linder S et al. Calpainmediated Bid cleavage and calpain-independent Bak modulation: two separate pathways in cisplatin-induced apoptosis. Mol Cell Biol 2002; 22: 3003-3013.

75. Kondo $\mathrm{M}$, Akashi $\mathrm{K}$, Domen J, Sugamura $\mathrm{K}$, Weissman IL. Bcl-2 rescues lymphopoiesis, but not B or NK cell development, in common $\gamma$ chain-deficient mice. Immunity 1997; 7: 155-162. 
76. Sarig R, Zaltsman Y, Marcellus RC, Flavell R, Mak TW, Gross A. BID-D59A is a potent inducer of apoptosis in primary embryonic fibroblasts. J Biol Chem 2003; 278: 10707-10715.

77. Yeretssian G, Correa RG, Doiron K, Fitzgerald P, Dillon CP, Green DR et al. Nonapoptotic role of BID in inflammation and innate immunity. Nature 2011; 474: 96-99.

78. Deveraux QL, Leo E, Stennicke HR, Welsh K, Salvesen GS, Reed JC. Cleavage of human inhibitor of apoptosis protein XIAP results in fragments with distinct specificities for caspases. EMBO Journal 1999; 18: 5242-5251.

79. Riedl SJ, Renatus M, Schwarzenbacher R, Zhou Q, Sun C, Fesik SW et al. Structural basis for the inhibition of caspase-3 by XIAP. Cell 2001; 104: 791-800.

80. Eckelman BP, Salvesen GS, Scott FL. Human inhibitor of apoptosis proteins: why XIAP is the black sheep of the family. EMBO Rep 2006; 7: 988-994.

81. Lu M, Lin SC, Huang Y, Kang YJ, Rich R, Lo YC et al. XIAP induces NF-kappaB activation via the BIR1/TAB1 interaction and BIR1 dimerization. Mol Cell 2007; 26: 689-702.

82. Silke J, Ekert PG, Day CL, Hawkins CJ, Baca M, Chew J et al. Direct inhibition of caspase 3 is dispensable for the anti-apoptotic activity of XIAP. EMBO J 2001; 20: 3114-3123.

83. Rothe M, Pan M-G, Henzel WJ, Ayres TM, Goeddel DV. The TNFR2-TRAF signaling complex contains two novel proteins related to baculoviral inhibitor of apoptosis proteins. Cell 1995; 83: 1243-1252.

84. Uren AG, Pakusch M, Hawkins CJ, Puls KL, Vaux DL. Cloning and expression of apoptosis inhibitory protein homologs that function to inhibit apoptosis and/or bind tumor necrosis factor receptor-associated factors. Proc Nat Acad Sci USA 1996; 93 4974-4978.

85. Sun $\mathrm{C}$, Cai M, Gunasekera AH, Meadows RP, Wang H, Chen $\mathrm{J}$ et al. NMR structure and mutagenesis of the inhibitor-of-apoptosis protein XIAP. Nature 1999; 401: 818-822.

86. Huang Y, Park YC, Rich RL, Segal D, Myszka DG, Wu H. Structural basis of caspase inhibition by XIAP: differential roles of the linker versus the BIR domain. Cell 2001; 104 781-790.

87. Hunter AM, LaCasse EC, Korneluk RG. The inhibitors of apoptosis (IAPs) as cance targets. Apoptosis 2007; 12: 1543-1568.

88. Galban S, Duckett CS. XIAP as a ubiquitin ligase in cellular signaling. Cell Death Differ 2010; 17: 54-60.

89. Damgaard RB, Gyrd-Hansen M. Inhibitor of apoptosis (IAP) proteins in regulation of inflammation and innate immunity. Discov Med 2011; 11: 221-231.

90. Schile AJ, Garcia-Fernandez M, Steller H. Regulation of apoptosis by XIAP ubiquitinligase activity. Genes Dev 2008; 22: 2256-2266.

91. Ryoo HD, Bergmann A, Gonen H, Ciechanover A, Steller H. Regulation of Drosophila AP1 degradation and apoptosis by reaper and ubcD1. Nat Cell Biol 2002; 4: 432-438.

92. Gyrd-Hansen M, Meier P. IAPs: from caspase inhibitors to modulators of NF-kappaB, inflammation and cancer. Nat Rev Cancer 2010; 10: 561-574.

93. Conte D, Liston P, Wong JW, Wright KE, Korneluk RG. Thymocyte-targeted overexpression of xiap transgene disrupts $\mathrm{T}$ lymphoid apoptosis and maturation. Proc Natl Acad Sci USA 2001; 98: 5049-5054.

94. Harlin H, Reffey SB, Duckett CS, Lindsten T, Thompson CB. Characterization of XIAPdeficient mice. Mol Cell Biol 2001; 21: 3604-3608.

95. Olayioye MA, Kaufmann H, Pakusch M, Vaux DL, Lindeman GJ, Visvader JE. XIAPdeficiency leads to delayed lobuloalveolar development in the mammary gland. Cell Death Differ 2005; 12: 87-90.

96. Scaffidi C, Fulda S, Srinivasan A, Friesen C, Li F, Tomaselli KJ et al. Two CD95 (APO-1/ Fas) signaling pathways. EMBO J 1998; 17: 1675-1687.

97. Algeciras-Schimnich A, Shen L, Barnhart BC, Murmann AE, Burkhardt JK, Peter ME. Molecular ordering of the initial signaling events of CD95. Mol Cell Biol 2002; 22 207-220.
98. Wilson TR, McEwan M, McLaughlin K, Le Clorennec C, Allen WL, Fennell DA et al. Combined inhibition of FLIP and XIAP induces Bax-independent apoptosis in type II colorectal cancer cells. Oncogene 2009; 28: 63-72.

99. Deveraux QL, Takahashi R, Salvesen GS, Reed JC. X-linked IAP is a direct inhibitor of cell-death proteases. Nature 1997; 388: 300-304.

100. Du C, Fang M, Li Y, Li L, Wang X. Smac, a mitochondrial protein that promotes cytochrome $c$-dependent caspase activation by eliminating IAP inhibition. Cell 2000; 102 33-42.

101. Verhagen AM, Ekert PG, Pakusch M, Silke J, Connolly LM, Reid GE et al. Identification of DIABLO, a mammalian protein that promotes apoptosis by binding to and antagonizing inhibitor of apoptosis (IAP) proteins. Cell 2000; 102: 43-53.

102. Suzuki Y, Imai Y, Nakayama H, Takahashi K, Takio K, Takahashi R. A serine protease, $\mathrm{HtrA} 2$, is released from the mitochondria and interacts with XIAP, inducing cell death. $\mathrm{Mol}$ Cell 2001; 8: 613-621.

103. Hegde R, Srinivasula SM, Zhang Z, Wassell R, Mukattash R, Cilenti L et al. Identification of $\mathrm{Omi} / \mathrm{HtrA} 2$ as a mitochondrial apoptotic serine protease that disrupts inhibitor of apoptosis protein-caspase interaction. J Biol Chem 2002; 277: 432-438.

104. Varfolomeev E, Alicke B, Elliott JM, Zobel K, West K, Wong H et al. X chromosome-linked inhibitor of apoptosis regulates cell death induction by proapoptotic receptor agonists. $J$ Biol Chem 2009; 284: 34553-34560.

105. Ogasawara J, Watanabe-Fukunaga R, Adachi M, Matsuzawa A, Kasugai T, Kitamura Y et al. Lethal effect of the anti-Fas antibody in mice. Nature 1993; 364: 806-809.

106. Holler N, Tardivel A, Kovacsovics-Bankowski M, Hertig S, Gaide O, Martinon F et al. Two adjacent trimeric Fas ligands are required for Fas signaling and formation of a deathinducing signaling complex. Mol Cell Biol 2003; 23: 1428-1440.

107. Hinz S, Trauzold A, Boenicke L, Sandberg C, Beckmann S, Bayer E et al. Bcl-XL protects pancreatic adenocarcinoma cells against CD95- and TRAlL-receptor-mediated apoptosis. Oncogene 2000; 19: 5477-5486.

108. Deng $Y$, Lin $Y$, Wu X. TRAIL-induced apoptosis requires Bax-dependent mitochondria release of Smac/DIABLO. Genes Dev 2002; 16: 33-45

109. Fulda S, Meyer E, Debatin KM. Inhibition of TRAIL-induced apoptosis by Bcl-2 overexpression. Oncogene 2002; 21: 2283-2294.

110. Gonzalvez F, Ashkenazi A. New insights into apoptosis signaling by Apo2L/TRAIL. Oncogene 2010; 29: 4752-4765.

111. Ashkenazi A. Targeting death and decoy receptors of the tumour-necrosis factor superfamily. Nat Rev Cancer 2002; 2: 420-430.

112. Galban S, Hwang C, Rumble JM, Oetjen KA, Wright CW, Boudreault A et al. Cytoprotective effects of IAPs revealed by a small molecule antagonist. Biochem J 2009 ; 417: $765-771$.

113. Dai Y, Liu M, Tang W, Li Y, Lian J, Lawrence TS et al. A Smac-mimetic sensitizes prostate cancer cells to TRAIL-induced apoptosis via modulating both IAPs and NF-kappaB. BMC Cancer 2009; 9: 392

114. Dineen SP, Roland CL, Greer R, Carbon JG, Toombs JE, Gupta P et al. Smac mimetic increases chemotherapy response and improves survival in mice with pancreatic cancer. Cancer Res 2010; 70: 2852-2861.

115. Sun $Q$, Zheng $X$, Zhang L, Yu J. Smac modulates chemosensitivity in head and neck cance cells through the mitochondrial apoptotic pathway. Clin Cancer Res 2011; 17: 2361-2372.

116. Vaux DL. Inhibitor of Apoptosis (IAP) proteins as drug targets for the treatment of cancer. F1000 Biol Rep 2009; 1: 79

117. Varfolomeev E, Blankenship JW, Wayson SM, Fedorova AV, Kayagaki N, Garg P et al IAP antagonists induce autoubiquitination of c-IAPs, NF-kappaB activation, and TNFalpha-dependent apoptosis. Cell 2007; 131: 669-681.

118. Vince JE, Wong WW, Khan N, Feltham R, Chau D, Ahmed AU et al. IAP antagonists target cIAP1 to induce TNFalpha-dependent apoptosis. Cell 2007; 131: 682-693. 